\title{
MedieVAl COMPLEXITY: \\ CONVIVENCIA AND THE CONSTRUCTION OF RELIGIOUS IDENTITY IN MOZARABIC APOLOGY (ELEVENTH THROUGH THIRTEENTH CENTURY)
}

\section{Jason Busic}

Scholarship has long emphasized the complexity of medieval Iberia and the convivencia of Muslims, Jews, and Christians. Whereas the debate between Américo Castro and Sánchez Albornoz posited the binaries of cultural exchange and cultural isolation, more recent work has shown that the nature of this coexistence varied situationally from intellectual cooperation with and tolerance of religious others to animosity, oppression, and violence in Christian and Muslim territories. ${ }^{1}$ Further, while cultural and religious fluidity characterized this period, anxiety over maintaining or constructing frontiers to resist this fluidity also regularly surfaced. ${ }^{2}$ This essay addresses the problem of religious identity in the multi-confessional atmosphere of medieval Iberia in a textual tradition attributed to the Mozarabs, Christians culturally and linguistically associated with al-Andalus. ${ }^{3}$

The Mozarabs are emblematic of the experience of convivencia, since their extant religious works synthesize the archives of the Latin

\footnotetext{
${ }^{1}$ For an introduction to the development of the debate over Convivencia, beginning with the Castro-Albornoz debate, see Kenneth Baxter Wolf's "Convivencia in Medieval Spain: A Brief History of an Idea," Religion Compass 3/1 (2009): 72-85. Also see Connie Scarborough, introduction to Revisiting Convivencia in Medieval and Early Modern Iberia, ed. Connie Scarborough (Newark, DE, 2014), 9-30.

${ }^{2}$ David Nirenberg, Neighboring Faiths: Christianity, Islam, and Judaism in the Middle Ages and Today (Chicago, 2014); Janina M. Safran, Defining Boundaries in al-Andalus (Ithaca, 2013).

${ }^{3}$ The present author is aware of the problematic nature of the term "Mozarabs" to refer to the heterogeneous Christian communities normally designated by it, ranging from the Latin authors of ninth-century Córdoba to Christian-Arabic writers in Christian Toledo (conquered in 1085 CE). However, "Mozarab" is employed throughout the present analysis, in part due to scholarly convention and, in part, because the works analyzed here were authored by Arabicized Christians. For the term's origins and usage, see Cyrille Aillet, Les mozarabes: Christianisme, islamisation et arabisation en Péninsule Ibérique (IX ${ }^{e}-X I I^{e}$ siècle) (Madrid, 2010), 2-9; Aillet, introduction to ¿Existe una identidad mozárabe? Historia, lengua y cultura de los cristianos de al-Andalus (siglos IXXII), ed. Aillet et al. (Madrid, 2008), xi-xii; and Richard Hitchcock, Mozarabs in Medieval and Early Modern Spain: Identities and Influences (Hampshire, 2008), ix-x, xviii-xix.
} 
West and the Islamic Mediterranean. As such, the Mozarabic literary corpus often serves as an example of co-existence and intellectual exchange; when it does not apparently fit this paradigm, binary readings opposing tolerant Christians and religious zealots develop. The clearest example of this kind of reading juxtaposes the Latin-writing Mozarabs of ninth-century Umayyad Córdoba and later Arabicized Christians. The former oppose adoption of Arabic, closely associated with Islam, in favor of linguistic and cultural isolation, while the latter embrace Arabic culture and find fruitful ways to relate to Islam. ${ }^{4}$ Whereas antiassimilationists maintain a distinct Western Christian identity through language (i.e. Latin), the assimilated exemplify fluid identities through Arabization and Islamization. ${ }^{5}$ The issue that arises, then, is whether the adoption of the religious other must necessarily relativize one's own religious claims and identity.

The present essay questions the assumption that Arabization and Islamization result principally in the blurring of religious boundaries and, consequently, religious identity. It explores how a set of Christian-Arabic texts constructs religious identity through the very fluidity that challenges it. The analysis draws on four works that play a key role in current debates on Arabization, Islamization, and religious identity in the theological thought of the Mozarabs: Mașhaf al- 'ălam al-kā'in (Book of the Existing World, eleventh or twelfth century), Risälat al-Qüțì (Letter

\footnotetext{
${ }^{4}$ See, for example, Jessica Coope, The Martyrs of Córdoba: Community and Family Conflict in an Age of Mass Conversion (Lincoln, 1995); Iván Pérez Marinas, Sansón de Córdoba: vida y pensamiento (Madrid, 2012), 42, 71-74, 220-25; Manuel Cecilio Díaz y Díaz, "Los mozárabes: una minoría combativa," in ¿Existe una identidad mozárabe?, 7; Sidney H. Griffith, The Church in the Shadow of the Mosque: Christians and Muslims in the World of Islam (Princeton, 2008), 67; Urvoy, "Influence islamique sur le vocabulaire d'un psautier arabe d'al-Andalus," Al-Qantara 15/2 (1994): 510; Maria Rosa Menocal, Ornament of the World: How Muslims, Jews and Christians Created a Culture of Tolerance in Medieval Spain (Boston, 2002), 66-72.

${ }^{5}$ Charles Tieszen, Christian Identity amid Islam in Medieval Spain (Leiden, 2013), 3435. On Islamization among the Mozarabs and its consequences for religious identity, also see Aillet, "Recherches sur le christianisme Arabisé," in ¿Existe una identidad mozárabe?, 91-134; Mayte Penelas, "El Kitāb Hurūšiyūš y el 'Texto mozárabe de la historia universal' de Qayrawān: Contenidos y filiación de dos crónicas árabes cristianas," in ¿Existe una identidad mozárabe?, 134-57; Mayte Penelas, "Linguistic Islamization of the 'Mozarabs' as attested in a late ninth-century chronicle," in Language of Religion-Language of the People: Medieval Judaism, Christianity and Islam, ed. Ernst Bremer, et al. (Munich, 2006), 103-14; Hanna Kassis, "Arabic-Speaking Christians in al-Andalus in an Age of Turmoil (Fifth/Eleventh Century until A.H. 478/A.D. 1085)," Al-Qantara 15/2 (1994): 401-22; Marie-Thérèse Urvoy, "Influence islamique sur le vocabulaire d'un psautier arabe d'alAndalus,"Al-Qantara 15/2 (1994): 509-17.
} 
of the Goth, $1147 \mathrm{CE}$ ), Tathlith al-wahdānīya (Trinitizing of the Unity, ca 1220), and marginalia contained in Madrid, Biblioteca Nacional de España (BNE), MS 10018, which probably date between the tenth and eleventh centuries. ${ }^{6}$ The authors of these texts negotiate identity primarily through exegesis, that is, how to appropriately understand revelation. Scriptural exegesis establishes continuity with the past while also defining who rightly lays claim to this continuity. As Szpiech has argued, "Within the multiconfessional world of the medieval Mediterranean, exegesis was always a double-valenced phenomenon that pressed against the boundaries between selfhood and otherness, community and outsider." 7 The texts studied here are relevant to Mozarabic religious identity because among their central concerns is Christology, which stands at the heart of how their authors define themselves in relation to Islam and other Christian communities. In their expositions of the Incarnation, whether as apology, confession, or study, Mașhaf, Risāla, Tathlìth, and marginalia in MS 10018 adopt and adapt the language of the Islamic Mediterranean from contemporary debates within Muslim theological circles and Christian-Arabic apology from the East. However, while seeming to place these Christian texts closer to those of Muslim traditions, this appropriation simultaneously becomes the means by which these texts construct religious identity. Through them, their authors define religious borders and establish continuity not only with Christianity, but also with the Latin Christian tradition.

\section{ThE PrIMARY Works: DATING, AUTHORShIP, AND MOZARABIC IDENTITY}

The texts under study come from distinct times and places, but they also share language and arguments pointing to a common concern over religious identity. Maṣhaf al- 'âlam al-kā'in, Risālat al-Qūțì, and Tathlìth

\footnotetext{
${ }^{6}$ The cited texts figure importantly into discussions of Mozarabic intellectual culture and identity in the following studies: Aillet, Les mozarabes; Daniel Potthast, Christen und Muslime im Andalus: Andalusische Christen und ihre Literatur nach religionspolemischen Texten des zehnten bis zwölften Jahrhunderts (Wiesbaden, 2013); Tieszen, Christian Identity amid Islam in Medieval Spain; and Thomas Burman, Religious Polemic and the Intellectual History of the Mozarabs, ca. 1050-1200 (Leiden, 1994). Only Aillet considers the annotations of BNE MS 10018, and Tieszen excludes Mașhaf from his study.

${ }^{7}$ Ryan Szpiech, introduction to Medieval Exegesis and Religious Difference: Commentary, Conflict, and Community in the Premodern Mediterranean, ed. Ryan Szpiech (New York, 2015), 2.
} 
al-wahdānīya survive solely in Muslim refutations of Christianity. Mașhaf and Tathlīth are cited in al-I 'ām of Abū al- 'Abbās al-Qurțubī (d. 1258), who writes primarily in response to Tathlith. ${ }^{8}$ The identity of the Christian authors remains obscure. Al-Qurțubī places Tathlīth's origins in Christian Toledo, indicating that he found it circulating in his native Córdoba. ${ }^{9}$ On the other hand, the imām attributes Mașhaf to "your leading teacher and your greatest bishop Aughushtīn," whom he cites in order to shame Tathlith's author for poor argumentative method. ${ }^{10}$ Burman speculates that this Aghushtīn may be identified as a priest from Toledo, known as a theologian and living in the first half of the twelfth century. ${ }^{11}$ However, al-Qurtubī likely cites the bishop of Hippo for polemical effect, and there may be no real "Aghushtīn" behind the text. Consequently, it need not originate in Christian Toledo. Aillet and Potthast advocate an earlier dating of Mașhaf due to similarities with Eastern apology already circulating in the Western Mediterranean as early as the ninth century and well established by the eleventh. ${ }^{12}$ Yet Mașhaf and Tathlìth present strikingly similar Trinitarian and Christological arguments that demonstrate a common theological tradition in medieval Iberia linked to kalām (rational theology in Arabic). ${ }^{13}$ Such tradition suggests a self-conscious attempt to construct communal identity in view of the religious other, in this case, Islam, and to do so through an archive common to the medieval Mediterranean.

\footnotetext{
${ }^{8}$ The full title is al-I 'ām bi-mā fì dīn al-nasārā min al-fasād wa-awhām wa-izhār mahāsin dīn al-islām wa-ithbāt nubūwat nabīnā Muhammad 'alayhi al-șalāt wa-al-salām, ed. Aḥmad Hijāzī al-Saqqā (Cairo, 1980). Kaddouri has identified the once enigmatic alQurțubī as Abū l-'Abbās Aḥmad b. 'Umar b. Ibrāhīm al-Anșārī al-Qurțubī (d. 1258), "Identificación de 'al-Qurțubī,' autor de al-I lām bimā fì dīn al-nașārāa min al-fasād wa-lawhām," Al-Qantara 21 (2000): 215-19.

${ }^{9}$ al-Qurțubī, al-I lām, 42.

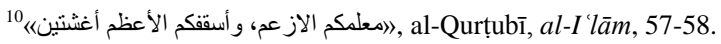

${ }^{11}$ Burman, Religious Polemic, 82-84.

${ }^{12}$ Aillet, Les mozarabes, 217-19; Potthast, Christen und Muslime im Andalus, 325-26. I have recently been made aware of the importance of Potthast's study, but due to my limited German, I have generally limited my references to easily accessible charts summarizing content in the narrative and sections whose titles indicate relevant material.

${ }^{13}$ Burman noted this similarity two decades ago in Religious Polemic, 81; Tieszen considers the two texts so similar that he excludes Maṣhaf from his study, Christian Identity, 12 .
} 
Aḥmad b. 'Abd al-Khazrajī, native of Córdoba, includes Risālat al$Q \bar{u} t \bar{l}$ in his twelfth-century polemic Maqāmi al-sulbān. ${ }^{14}$ The polemical work originates at the bequest of al-Khazrajī's co-religionists in Toledo, where he spent two years as prisoner from 1145 to 1147 . A priest "from the Gothic lineage" (thus, "al-Qūṭị”) was attempting to proselytize Muslims, and Maqāmi provides a reasoned rebuttal to this priest's efforts. ${ }^{15}$ The Risāla is purportedly al-Qūṭì's work sent to the Muslim interlocutor, but the text raises certain difficulties that have led scholars to question its authenticity. ${ }^{16}$ These difficulties include theological errors and incorrect citations of the Hebrew Bible. As Burman has argued, however, Christian writers in the Middle Ages often misquote the Bible as they draw from memory or produce ad hoc translations, and Risāla accurately reflects extant Mozarabic apology whose authenticity is not questioned, including Mașhaf and Tathlīth. ${ }^{17}$ Risāla also reflects the exalted yet sympathetic tone one would expect from a mission-oriented text, and a zealous missionary could plausibly alter biblical passages for the purposes of proselytization. Further, apparent theological error may be due to poor formation: not all clergy received rigorous theological training. Finally, Latin influence pervades Risāla, in vocabulary and grammar. The most grievous theological error, relating to the term "hypostasis," may be explained in light of this influence, as argued later in this essay. Most importantly, however, Risāla employs a vocabulary similar to that found in Mașhaf and Tathlith in its Christological exposition, and thus points to a conceptual archive common to all three texts.

The marginalia in MS 10018 are distinct from the other works analyzed here because they are inward looking. In other words, their author or authors do not explicitly address religious others, and certainly not Muslims. Rather, these annotations represent an attempt to understand the primary texts of the manuscript. Nonetheless, the

\footnotetext{
${ }^{14}$ Aḥmad b. 'Abd al-Șamad al-Khazrajī, Maqāmi' al-ṣulbān, ed. 'Abd al-Majīd alSharfī (Tunis, 1975). For the Risāla and its frame, see 29-39.

15 《نسبه من الغوطي", al-Khazrajī, Maqāmi ', 29-30.

16 See Diego R. Sarrió Cucarella, Muslim-Christian Polemics Across the Mediterranean: The Splendid Replies of Shihāb al-Dīn al-Qarāfì (d. 864/1285) (Leiden, 2015), 91-92; Aillet, Les mozarabes, 221-22; Tieszen, Christian Identity, 212-20; Burman, Religious Polemic, 63-65, 66-70.

${ }^{17}$ Burman, Religious Polemic, 68; Tieszen, too, considers Risāla at least representative of Christian identity, even if not authored by a Christian, Christian Identity, 213-15.
} 
marginalia in question rightly enter into the current analysis, because they focus on Christologically relevant passages in the manuscript while the vocabulary employed reflects that of Mașhaf, Risāla, and Tathlïth. MS 10018 is from the late ninth or early tenth century and contains a copy of Beatus of Liebana's Epistula ad Elipandum (785 CE), Samson of Córdoba's Apologeticus contra perfidos ( $864 \mathrm{CE}$ ), and a collection of sententiae. Arabic annotations in several different hands and from different time periods appear exclusively in the margins of Beatus's and Samson's works. Van Koningsveld believes that these and most Arabic marginalia in Latin manuscripts originate in eleventh- and twelfthcentury Toledo, since there the Mozarabs would have had renewed interest in the study of Latin. ${ }^{18}$ Aillet, however, has argued for a more long-standing tradition. He points out that the annotations in MS 10018 show characteristics of early and late Arabic handwriting, and the oldest marginalia may be from as early as the late ninth or early tenth century and be contemporary to the manuscript. ${ }^{19}$ Aillet also shows that the Arabic marginalia found in Mozarabic manuscripts have multiple ends, from correcting copyist errors and language study to commenting upon theologically important passages. ${ }^{20}$ The annotations analyzed in this article show characteristics of tenth- or eleventh-century script, as described by Aillet, and summarize Christological passages in Beatus's and Samson's works.

Mașhaf, Risāla, Tathlīth, and the annotations of MS 10018 of the BNE thus originate in a variety of contexts and represent varying purposes, including apology, evangelization, and study. Nonetheless, the texts share similar theological concerns, most especially in terms of Christology. Mașhaf and Tathlith provide an elaborate defense of the Incarnation by drawing on the Qur'ān and Islamic kalām while their authors argue that God's indwelling of man is consistent with earlier revelation and does not compromise divine transcendence. In missionary zeal, the author of Risäla proclaims that the Word Incarnate is the culmination of revelation, and that this incarnation made possible the union between mankind and God as well as mankind's salvation. The

\footnotetext{
${ }^{18}$ Van Koningsveld, "Christian Arabic Literature from Medieval Spain: An attempt at Periodization," in Christian Arabic Apologetics during the Abbasid Period (750-1258), ed. S. Khalil Samir and J.S. Nielsen (Leiden, 1994), 219. 154-57.

${ }^{19}$ Aillet, "Recherches sur le christianisme arabisé," 95-100; Aillet, Les mozarabes,

${ }^{20}$ Aillet, Les mozarabes, 172-74.
} 
annotations of MS 10018 contemplate how Christ is both man and God, limited and transcendent, and how the faithful access the divine only through the flesh of the Messiah. The arguments in these texts draw on diverse sources including Islamic theology, Christian-Arabic apology from the East, and the Latin Christian tradition. That this is so is widely recognized. However, how this synthesis of different intellectual archives contributed to the construction of Mozarabic identity is still under debate. Indeed, some work has questioned if such an identity even exists. ${ }^{21}$ The following pages argue that the Christological arguments of the texts in question reveal a conscious manipulation of the intellectual language of the medieval Mediterranean, closely associated with Islam and Eastern Christianity, as an attempt to approximate those traditions while still claiming continuity with the Latin West. As such, Mașhaf, Tathlìth, Risāla, and the marginalia in question establish frontiers that maintain this Western identity before Islam as well as before competing Christian communities.

\section{UNDERSTANDING THE INCARNATION: REVELATION, CHRIST, AND KALĀM}

The arguments and vocabulary employed throughout Maṣhaf, Risāla, and Tathlith show that their authors consciously draw on debates taking place within Muslim theological circles throughout the medieval period, and the marginalia of MS 10018 reflect some of these concerns, too. Of particular concern to us here is the way discussions regarding God's relationship to creation provided a conceptual framework for Christians to defend the Incarnation. The Qur'ān describes God as transcendent yet immanent, beyond human comprehension yet intimately involved in human affairs. As absolutely One, God is indivisible and unlike creation, yet the Qur'ān nonetheless describes him in anthropomorphic terms such as powerful, knowing, living, willing, speaking. Various theological schools developed different ways to address these conundrums, and how they did so had important consequences for understanding revelation and the Qur'ān. ${ }^{22}$ One early speculative school, the Mu'tazila, attempted to

\footnotetext{
${ }^{21}$ Aillet, Les mozarabes, xviii, 33-35; the question is also explored throughout the cited volume, ¿Existe una identidad mozárabe?.

${ }^{22}$ For an overview of kaläm as related to the present discussion, see Tilman Nagel, The History of Islamic Theology: From Muhammad to the Present, trans. Thomas Thornton (Princeton, 2000), 97-110, 128-58; Nader El Bizri, "God: Essence and Attributes," in The Cambridge Companion to Classical Islamic Theology, ed. Tim Winter (Cambridge, 2008),
} 
preserve God's unity without denying his attributes by arguing that these attributes were essentially him: God's knowledge was none other than him, his power none other than him, and so forth. ${ }^{23}$ The Mu'tazila maintained that God, one and possessed of no limits, was present everywhere yet contained nowhere. ${ }^{24}$ As the Creator was one and his attributes were none other than him, the Mu tazila taught that the Qur'ān was created - a limited word distinct from divine speech and revealed to humankind, perceptible to the senses. ${ }^{25}$ This school reached its zenith in the early ninth century under Caliph al-Ma'mūn (d. 833), who attempted to impose the doctrine of the created nature of the Qur'ān. Though the school lost dominance in the tenth century, the doctrines attributed to the Mu'tazila long remained a target for theological debate within mainstream Sunnī circles.

Sunn̄̄ schools responded vigorously to the $\mathrm{Mu}$ 'tazila, because $\mathrm{Mu}$ 'tazilite speculation appeared to place human reason above divine revelation and even contradict it. The Hanbalites, whose founding teacher was Ahmad b. Hanbal (d. 855), held that the Mu'tazila had left the fold of the community of believers, reducing God's attributes to nothing and contradicting divine revelation. Rather than relying on human reason, the Hanbalites argued, the faithful must unquestionably accept the Qur'ān and the traditions (ahāidith). Where difficulties exist or revelation contradicts reason, one should assent to revelation "without asking how" ("bi-lā kayf") it is true. ${ }^{26}$ For example, the Qur'ān asserts that God sits and judges from the throne; how this is so should not be investigated. ${ }^{27}$ Further, the Hanbalites asserted, the Qur'ān, as God's speech, in

121-40; and James Pavlin, "Sunni kalām and theological controversies," in History of Islamic Philosophy, ed. Sayyed Hossein Nasr and Oliver Leaman (London, 1996), 105-18.

23 Muḥammad b. 'Abd al-Shahrastān̄̄, al-Milal wa-l-naḥal, ed. Aḥmad Fahmī Muhammad, $2^{\text {nd }}$ ed. (Beirut, 1992), 38-39; these passages are also available in English translation, see "Divergent Schools of Thought: Shahrastānī's Doxography of Muslim Schools," trans. Michael A. Sells, in John Renard, ed., Islamic Theological Themes: A Primary Source Reader (Oakland, 2014), 138-40.

${ }^{24}$ See Nagel, The History of Islamic Theology, 102-103; el-Bizri, “God: Essence and Attributes," 127.

${ }^{25}$ 'Abd al-Jabbār b. Aḥmad al-Asad Abādī, al-Ușūl al-khamsa, ed. Fayṣal Badīr 'Awn (Kuwait, 1998), 86-87.

${ }^{26}$ Khalid Blankinship, "The Early Creed," The Cambridge Companion to Classical Islamic Theology, 53; El Bizri, "God: Essence and Attributes," 126.

27 "Hanbalī Traditionalist Creed," trans. W. Montgomery Watt, in John Renard, ed., Islamic Theological Themes, 108. 
whatever form, must be uncreated, since God was never without this divine attribute. ${ }^{28}$ The Sunn̄̄ theologian Abū al-Hasan al-Ash'arī (d. 936), founder of the Ash'arites, likewise rejected the Mu'tazila's reduction of God's attributes to the divine essence. However, he did not reject the speculative methodology of the Mu'tazila; rather, he subordinated it to revelation. God, as Creator ("khāliq"), remains transcendent of creation ("makhlūq") while yet sustaining it. ${ }^{29}$ Al-Ash 'arī also distinguishes between essential attributes ("ṣifăt al-dhāt") and those related to God's actions ("șifăt al-af' âl"); the former are eternal, because their opposite cannot describe God. ${ }^{30} \mathrm{Al}$-Ash 'arī further held that the Qur'ān was an uncreated manifestation of the attribute of speech while its copying and reciting was created, serving as a means through which one gained access to divine speech. ${ }^{31}$

The Mozarabic author of Mașhaf adopts the language of these debates, but he maintains distinctions that also oppose Christian doctrine to Muslim. For example, al-Ash 'arī accuses the Jahmīya, with whom the $\mathrm{Mu}$ 'tazila were often associated, of wrongly distinguishing between God's attribute of speech and that speech that Moses heard in the burning tree. $^{32}$ The Jahmiya argue that God "created a speech, speaking to him [Moses] by it." 33 In like manner, for the Jahmīya, the Qur' ān is a created, limited expression by which God manifests his unlimited oneness. The Sunnī theologian argues that Moses could not claim to have heard God speak if that speech had been created; rather, God spoke to Moses from

28 “Hanbalī”" in Renard, ed., Islamic Theological Themes, 109.

${ }^{29}$ Abū al-Hasan al-Ash'arī, Kitāb al-luma' fì al-radd 'alā ahl al-zigh wa-l-bda', ed. Hamūda Ghurāba (Cairo, 1955), 17-23.

${ }^{30} \mathrm{Al}$-Ash 'arī dedicates considerable space to the difference between essential and nonessential attributes; for examples, see Kitāb al-luma ', 25-31, 37-46.

${ }^{31}$ For al-Ash 'arī's arguments supporting the uncreated nature of the Qur'àn as God's speaking (《كلام الشا)), see Kitāb al-luma', 33-37, as well as al-Ash 'arī, al-Ibāna 'an ușūl aldiyāna, ed. Bashīr Muḥammad 'Uyūn, $3^{\text {rd }}$ ed. (Damascus, 1999), 72-96; for al-Ash 'arī’s distinction between the Qur'ān as God's uncreated speaking and the created nature of the recitation of the Qur'ān (اللفظ بالقرآن)), see the chapter "Faṣl ākhar fĩ ibānat madhhabihi fī kalām allāh" in Abū Bakr b. Fūrak, Mujarrad maqālāt al-shaykh Abì al-Hasan al-Ash 'arī, ed. Daniel Gimaret (Beirut, 1987), especially pp. 60-61.

${ }^{32}$ Despite differences, the Jahmīya and the Mu'tazila were regarded to hold similar doctrines on the divine attributes and the createdness of the Qur'ān; compare al-Ash 'arī's portrayal of Jahmīya teaching on the Qur'ān with that in 'Abd al-Jabbār, al-Ușūl alkhamsa, 86-87. For further discussion on the conflation of the Jahmiya and the Mu tazila regarding this doctrine, see Nagel, The History of Islamic Theology, 153-54.

33 "خلق كلام اكلمه بها》, al-Ash 'arī, al-Ibāna 'an uṣūl al-diyāna, 25. 
"behind a veil [i.e., the tree]." ${ }^{34}$ Further, according to al-Ash 'arī, if God's speaking in the Qur'ān (or to Moses) were created, it would lead to the absurd conclusion that God created his own speaking. ${ }^{35}$ Mașhaf likewise takes up the problem of divine speech as related to revelation in order to defend the Incarnation. Aghushtīn asks if Moses perceived a created voice or if he perceived the uncreated attribute of God's word. ${ }^{36}$ Since God is one and his attributes are none other than him, his speech cannot be "heard"; rather, "God created the voice, and made it a veil for his will which he made appear in it." 37 This created voice told Moses, "I am your Lord." ${ }^{38}$ This veiling neither limits the divinity nor robs God's right to worship; rather, Moses rendered that right to God through the veil. In like way, God veiled his Word in the Messiah, through which God speaks to mankind and through which mankind rightly honors God. ${ }^{39}$

Aghushtīn employs vocabulary and arguments parallel to those in Islamic theology as represented in al-Ash 'arī, and he approximates the Jahmīya. Significantly, even al-Ash'arī accuses the Jahmīya of advocating a theology similar to Christian doctrine on the Incarnation: the Jahmīya make the Qur' ān "an incarnate body that eats and drinks," nothing short of "a man." from any Muslim position: the permanence of the union between veil and divinity, and the nature of this union. In other revelations, the veil has a beginning and an end, but Christ remains forever. ${ }^{41}$ Aghushtīn further argues that people naturally recognize a hierarchy among created things, and that the more something is like its Creator, the more honor it is accorded. Now Christ's flesh was so exalted in the union with the Word, "that it is united with its Creator, and is the most exalted of things." 42 Mașaf concludes that the Incarnation is the greatest divine revelation,

${ }^{34}$ 《من ور اء حجاب", al-Ash 'arī, al-Ibāna, 24-25.

${ }^{35}$ Al-Ash 'arī, al-Ibāna, 27.

${ }^{36}$ Al-Qurțubī, al-I lām, 143.

37 《اله خلق الصوت، وجعله حجابا لإر ادته التي اظهر ها فيه), al-Qurṭubī, al-I lām, 144.

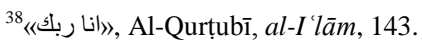

${ }^{39}$ Al-Qurțub̄i, al-I ' lām, 144-45.

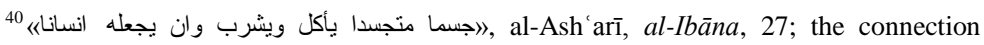
between the Jahmìya and the Christians is explicit in the beginning of the same section, 22.

${ }^{41}$ Al-Qurțubī, al-I ' lām, 143, 145.

42"ان يتصل بخالقه، ويكون اعز الاشباء《, al-Qurțubī, al-I lām, 144. 
since the divine approached the people in human likeness. ${ }^{43}$ These claims point to a deep void between Aghushtīn's theology and that of either the Sunn̄̄ or Mu'tazila, establishing boundaries between "Christian" and "Muslim." Namely, Mașhaf's explicit confusion between "created" and "Creator" resulting in their indistinguishable dignity in Christ, the one becoming divine through the other, opposes Sunnī and Mu'tazila. Further, Aghushtīn's assertion that Christ is different in dignity from other revelations implicitly negates the Qur'ānic concept of itself as but the same revelation contained in the Torah, Psalms, and Gospel. Mașhaf's approximation to Islam linguistically and conceptually is the means through which it delineates these doctrinal boundaries and establishes who belongs to the Christian fold and who lies outside of it, who grasps revelation and who does not.

Tathlitth presents Christological arguments similar to those found in Mașhaf, and in like way the author of Tathlith situates the discussion of the Incarnation in the tradition of kalām: he first addresses God's revelation to Moses in a voice and flame, and asks whether Moses heard the voice of God directly or through the intermediary of creation. ${ }^{44}$ The author claims that if the Muslim interlocutor answers that this voice was God's speech, then the Muslim has assigned a body to the divinity, which no one accepts. Therefore, Tathlith concludes, the sole viable explanation of the relationship connecting God's speech to the voice Moses heard is "that God created for him a speaking," and as such "a created word subsisting in his creation." 45 For the Mozarab, this preserves God's oneness and omnipresence while it corresponds to human need, only capable of perceiving what is his like in nature. ${ }^{46}$ This type of reasoning again reflects Muslim theological debates, as discussed above, and Tathlith approximates a position similar to the $\mathrm{Mu}$ 'tazilite understanding of revelation and divine speech. Like Mașhaf, Tathlith also asserts that worship is rightly rendered to God through such a veil. ${ }^{47}$ What is more, unlike Mașhaf, the author of Tathlith further approximates his Muslim interlocutor by claiming that revelation in Christ is the same as the revelation to Moses and the Prophets, therefore implicitly adopting the

\footnotetext{
${ }^{43}$ Al-Qurțubī, al-I ' lām, 145-46.

${ }^{44}$ Al-Qurțubī, al-I lām, 105.

45 4ان الله خلق له كلامای)، „كلاما مخلوقا قائما بخلقه, al-Qurṭubī, al-I lām, 105.

${ }^{46}$ Al-Qurțubī, al-I lām, 106.

${ }^{47}$ Al-Qurțubī, al-I lām, 115.
} 
Qur'ānic concept of the one revelation repeatedly manifested throughout history.

The similarities shared by Tathlith and Islamic debates in content, argument, and vocabulary are clear enough, but differences between Tathlīth's exposition and Mu'tazilite and Sunn̄i positions are also important. First, the Mozarab explains at length why the "one born speaking" was Incarnate and not another person of the Trinity. ${ }^{48}$ This claim is especially significant because it posits the divine attribute of "speech" as essentially God (like the Mu'tazila, but unlike the Sunnī), and delineates real functions and, therefore, existence of specific attributes (unlike the Mu'tazila). Moreover, Tathlith distinguishes between the prophets and Christ, stating that the prophets heard God through an intermediary and then preached; Jesus, on the other hand, was the intermediary. Whereas a prophet could conceivably alter God's message, the Messiah, like the flame appearing to Moses, was the message. ${ }^{49}$ This latter point is significant in the context of Muslim discussions of whether a prophet could alter God's revelation upon relating it to the people. The Mozarab effectively posits that Christ is no different from the Qur'ān-the Messiah, a man, is God's uncreated speech made present through created humanity. As in the case of Mașhaf, then, it is specifically through approximation to Islamic theology, its language and themes, that Tathlith articulates religious difference and identity in a way that writing in Latin could not.

Risālat al-Qūtī presents an approach distinct from Tathlīth or Mașhaf, but still engages with contemporary discussions within Muslim theological circles in order to define Christian doctrine. Risāla reads like an evangelical tract and lacks the subtle arguments found within the other two texts. Indeed, certain passages constitute a confession of faith: Christ, God's Word, descended from heaven, was Incarnate, suffered crucifixion and death, and then rose again. ${ }^{50}$ Further, the ransom offered by the Messiah through his blood is effective for all humanity, only individually ineffective when a person rejects it. ${ }^{51}$ What is of interest for the present analysis, however, is al-Qüțī's explanation of the Incarnation in the context of earlier divine manifestations. He, too, takes up the

\footnotetext{
${ }^{48}$ 《المتولد كلامال, al-Qurṭubī, al-I lām, 91.

${ }^{49}$ Al-Qurțubī, al-I lām, 115.

${ }^{50}$ Al-Khazrajī, Maqāmi`, 30-31.

${ }^{51}$ Al-Khazraj̄̄, Maqāmi ', 31.
} 
theme of revelations and the prophets before Christ, to whom God spoke through "his intermediaries." 52 Unlike Maṣhaf and Tathlith, however, Risāla posits that Christ is God's manifestation without intermediary, and is therefore unlike previous revelation. Al-Qūṭi writes, "he spoke to them in his essence without an intermediary between them and him," and "so he took up from [Mary] a veil." ${ }^{53}$ In Risāla, the term "intermediary" only describes prophets and messengers other than Christ, and "veil" only applies to Christ. Further, the veil is created, while the one speaking through it is divine. Consequently, Risāla's language approximates alAsh 'arī's position, which denies created intermediaries in divine speech while accepting that this speech comes "from behind a veil." ${ }^{54}$ This approximation, however, marks difference rather than similarity: Christ is again God's speech, his humanity a veil from which uncreated speech is made manifest.

The marginalia contained in BNE MS 10018 do not present a developed treatise on any one theme, but rather reflect the Mozarabic readers' intellectual concerns as related to the primary texts, Beatus's eighth-century polemic against Bishop of Toledo Elipandus and Samson's ninth-century Apologeticus. The oldest annotations may be contemporary to the manuscript copy or as late as the eleventh century. While these marginalia demonstrate that Beatus and Samson's annotators understood the content well, the Arabic vocabulary also participates in the intellectual life of the Islamic Mediterranean. The most striking examples are found in the margins of passages addressing the relationship between Christ and other divine revelations and Christ and the books of Scripture. With regard to the former, chapter XIX of his Apologeticus, "Quid sit uenire quidue manere Dei," Samson attempts to explain what Scripture means when it says that God visits or speaks to the faithful. ${ }^{55}$ This discussion also leads the ninth-century abbot to consider the uniqueness of revelation in Christ. ${ }^{56}$ The Arabic annotations follow Samson's argument word for word, employing the term "al-hujūb al-makhlūqa al-hạmila" ("created veils bearing [the message]”) for

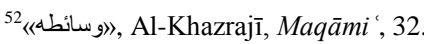

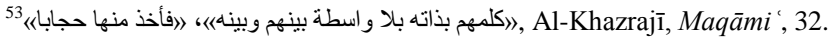

54 "إن ور اء حجاب), al-Ash 'arī, al-Ibāna, 24-25.

${ }^{55}$ Apologeticus, 614. Citations from the Latin text of Samson's Apologeticus come from Juan Gil's Corpus muzarabicorum (Madrid, 1973).

${ }^{56}$ Apologeticus, 614-15. 
Samson's "subiectas creaturas," "ṣūra" ("form") for "forma," and "hay' a" for "species." 57 These terms reveal recognition of distinctions in the Apologeticus. For example, Samson cites Fulgentius's De incarnatione, "When the Holy Spirit came in the form of a dove, it did not become a dove, as the Son became man." 58 The annotation reads, "[The Spirit] did not become dove for its drawing near in its form as the Word became man."59 The annotator makes Samson's language his and becomes a member of the same Latin tradition as the abbot.

Nonetheless, the annotator's words also place the Latin tradition in dialogue within a new linguistic archive. The annotations mirror the Latin argument, but the use of "veil" in a passage comparing Christ and other divine manifestations associate the annotations with a theological environment whose concerns respond to those of Islam. As noted, chapter XIX of the Apologeticus treats of God's movement, but specifically within Samson's larger discussion of God's oneness, fully present everywhere, neither contained in or excluded from any place or thing, whether in part or in whole. How then can one understand Christ's divinity or sensible revelation at all? Samson contends that God's speaking to mankind through created forms does not compromise divine transcendence. In like way, the marginalia assert, "His drawing near is not temporal or spatial, since he does not withdraw and the world is not in want of him. ${ }^{, 60}$ Paralleling the Latin text, the Arabic also associates the theology with debates in kaläm, such as when the Mu'tazila claim that, due to God's oneness, he cannot be spoken of temporally or spatially, "that bodies are not like him, and it is not permitted him what is permitted them concerning rising and declining and movement and change and composition." ${ }^{61}$ Further, the marginalia condense the content of the Apologeticus in such a way as to place the discussion of God's omnipresence visually closer to the problem of the Incarnation than in the Latin, suggesting a comparison of apologetical value. As in the case of

\footnotetext{
${ }^{57}$ BNE, MS 10018, 152v.

58 “'Spiritus,' ait [Fulgentius], 'Sanctus ueniens in specie columbe non columba factus est, sicut Filius factus est homo," Apologeticus, 614.

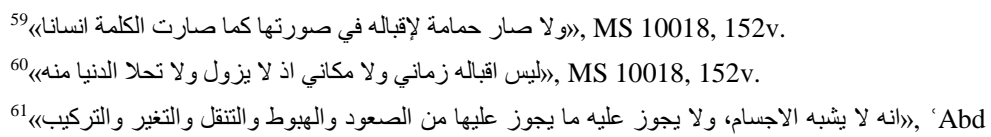
al-Jabbār, al-Uṣūl al-khamsa, 68; compare Richard Martin's translation of the fragment containing this passage, "Abd al-Jabbār's Mu tazilī Five Principles," Islamic Theological Themes, 162.
} 
the other tracts analyzed here, approximation ultimately leads to distinction: the divinity does not move, "but his coming into the world was his taking on the form of a slave.",62

\section{Christology, the Christian-Arabic Tradition, AND Religious IDENTITY}

Thus far, this analysis has argued that Arabization and Islamization among the Mozarabs of medieval Iberia does not solely obscure the sense of continuity and limits so fundamental to the construction of religious identity, particularly in relation to Islam. Rather, Mașhaf, Risāla, Tathlith, and the annotations in MS 10018 stake religious claims and construct identity specifically through approximation to the religious other. However, in the medieval Mediterranean, Christian communities also constituted "others," largely in terms of Christology. How did the Mozarabs construct religious identity in relation to these communities? The Latin West had long maintained the one-person, two-nature position of Chalcedon (451) by the time the Mozarabs wrote. Yet, as Burman showed two decades ago, the Mozarabs draw heavily on Eastern Christian thought. ${ }^{63}$ Aillet, Potthast, and Monferrer Sala, among others, have further elucidated the degree of Mozarabic debt to the ChristianArabic tradition of the East. ${ }^{64}$ For example, important parallels exist between 'Ammār al-Bașrī's (d. ca. 840) Kitāb al-burhān (The Book of Proof) and Mașhaf and Tathlïth. The Nestorian theologian defends the Incarnation by showing its consistency with the history of revelation, such as God's speaking to Moses through the flame, and argues that the Divinity "veiled himself" ("ihtajab") in the flesh of Christ, because humankind cannot perceive the invisible God except through the intermediary of creation. ${ }^{65}$ Several scholars have argued that the Nestorian influence in Mozarabic thought led the Mozarabs to

62 《بل كان اقباله للانيا اتخاذه صورة العبدر, MS 10018, 152v.

${ }^{63}$ Burman, Religious Polemic, 35-36, 45-46, 119-20.

${ }^{64}$ Aillet argues this point throughout part two (chapters 3-5) of Les mozarabes, but see especially 239-41; Potthast, "Mozarabismen und andalusische Christen," in Christen und Muslime im Andalus, 423-85; Juan Pedro Monferrer Sala, “Circularon textos cristianos orientales en al-Andalus?: Nuevos datos a partir de una muestra véterotestamentaria andalusí,” in ¿Existe una identidad mozárabe?, 167-210.

${ }^{65}$ 'Ammār al-Bașrī, Kitāb al-burhān in Apologie et controverses, ed. Michel Hayek (Beirut, 1977), 64-72. 
approximate or adopt a Christology foreign to Latin tradition, and thus blur religious boundaries. ${ }^{66}$ Using al-Bașrî’s Kitāb al-burhān as a point of comparison, however, the following pages argue that Mozarabic approximation to the language of non-Chalcedonian apology may also function to establish boundaries.

Mașhaf's argumentation is quite similar to the principle argument of al-Bașrî̀'s Christological apology in Kitāb al-burhān: both texts seek to demonstrate that God reveals himself according to humankind's needs, not divine power, and that the Incarnation is consistent with the creaturely veils by which he revealed himself throughout history. However, certain elements indicate an attempt on Aghushtīn's part to accommodate this apology to the Latin tradition. This accommodation can be subtle, such as when Aghushtīn writes, "And if honoring the veil with the honor of the one veiled therein is necessary, nothing remains upon us from the speaking save in the veil that he took up from us, and he is the Messiah., ${ }^{, 67}$ The pronoun "he" stands as subject to "Messiah," making of "Messiah" the one subject in which veil and divinity unite; neither is left to act on its own. This is significant if compared to Kitāb al-burhān, in which al-Bașrī maintains a sharp distinction between Christ's body and the divinity, so much so that the one serves as subject without the other. For example, al-Bașrī explains, "[The Creator] counseled us from our flesh and veiled himself with it and drew near to us with guidance, so he spoke to us from our substance, while he filled the heavens and the earth." ${ }^{68}$ As discussed above, though, Mașhaf so confuses "veil" and "divinity" that the former rightly declares "I am God" and receives worship. ${ }^{69}$ This language reflects a Theotokos theology, where the flesh born of Mary is rightly called God, and it falls within Latin tradition. But the distinction comes through approximation - apologetical arguments and terminology similar to Kitāb al-burhān take on new meaning and mark a distinct religious identity.

Tathlīth, like Mașhaf, appears to follow al-Bașrī's apology for the Incarnation quite closely, even going so far as to claim that God's

\footnotetext{
${ }^{66}$ Aillet, Les mozarabes, 231-34; Potthast, Christen und Muslime im Andalus, 333; Pérez Marinas, Sansón de Córdoba, 220-25.

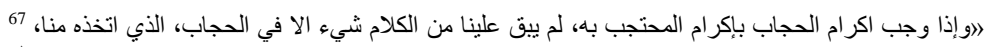

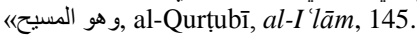

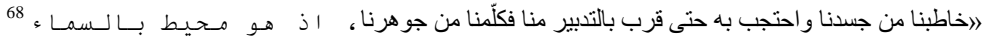

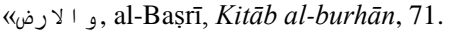

${ }^{69}$ Al-Qurțubī, al-I làm, 144-45.
} 
revelation in Christ is like God's revelation to Moses. ${ }^{70}$ However, Tathlith does not explicitly adopt a two-person Messiah, and certain passages suggest the author's identification with the Latin tradition. The first of Tathlith's Christological concerns is to establish why it is God's speaking or knowledge (i.e., the Son) that took up the flesh rather than the Father: "He took it up for the admonition of creation and exhortation is associated to the knowledge born as word, so it is called "son.",71 Tathlith explains that revelation is the work of God's speaking, and as such, the apology claims a natural link between incarnation and the Word. Though not opposed to its logic, this argument is absent from alBașrī’s Kitāb al-burhān. However, a conceptual parallel may be found in Tertullian. In Adversus Praxeam, the Word ("Sermo") is "sophia" or "sapientia," the rationality of God by which he creates and reveals, the exclusive means by which people may know God. ${ }^{72}$ Tertullian concludes, then, that all revelation in the Old Testament is ultimately through the Son, including the burning bush: "God could not converse with men on earth other than as the Word, who was to become flesh." ${ }^{73}$ Christian tradition in general associates revelation in the Old Covenant to that in Christ, but Tertullian's necessary link between the Word and all revelation is mirrored in Tathlith. As Burman has shown, the author of Tathlith draws on Latin Trinitarian apology, and so it also stands to reason that this Mozarab draws on Latin Christology. ${ }^{74}$ If this is the case, then Tathlith's author appropriates Eastern apology while incorporating it into Latin Christian tradition throughout the text.

Al-Qūṭ̂, too, differentiates through approximation to the theological tradition represented in al-Bașrī’s apology. A case in point is al-Qūṭ̂̄’s emphasis on how God speaks to mankind through Christ without an intermediary. As alluded to previously, Risāla posits, "[God] spoke to the world upon the tongues of his prophets whom he made his messengers and his intermediaries to his creation," but with Christ "he spoke to them

${ }^{70}$ Compare Tathlīth, p. 115, and Kitāb al-burhān, p. 66, in which both authors transition to the Incarnation declaring that it is just like God's presence in previous revelations. I 'Tām, 91.

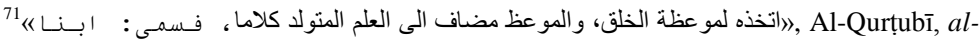

${ }^{72}$ Tertullian, Liber adversus Praxeam, PL 2:161, 174.

73 "Deus in terris cum hominibus conversari non alius potuit quam Sermo, qui caro erat futura," Tertullian, Liber adversus Praxeam, 175.

${ }^{74}$ Burman, Religious Polemic, 172-81. 
in his essence without an intermediary between them and him."75 AlBașrī, too, states that in Christ God came to call the people "to his knowledge upon the tongue of their flesh united to him without a messenger between him and them."76 And of course both al-Qūṭi and alBașrī employ the term "veil" to describe Christ's flesh. Nonetheless, Risāla's theology is distinct. For instance, he calls Mary "Mother of the Light," thus affirming the Virgin as Theotokos. ${ }^{77}$ He cites the first words of John's Gospel, but concludes them in his own: "In the beginning was the Word, and the Word was God' and he is created by way of his body and Creator by way of his soul." 78 The pronoun "he" joins God and the Word, and this "he" is also the one "created" and "Creator"; thus, like Mașhaf, divinity and humanity are so associated that they no longer act separately. The Mozarab situates this passage specifically in Western tradition when he writes, "so he descended in his essence from the heavens and was incarnate in the womb of the Virgin Mary.",79 The verb "to incarnate" is "iltahama," the favored term in the Iberian Peninsula and a calque for the Latin "incarnatus est," found, for example, in the Arabic Gospels of Iberia. "In the East, "tajassada" ("to become embodied") is the almost universal term, regardless of Christology, though it, too, appears alongside "iltaḥama" in Iberia. ${ }^{81}$ Al-Qūṭ̂̄ subsequently reflects, "his mother was before him in his humanity, and he was before her in his divinity, and he is the perfect divinity." "T2 The abstract quality of the terms "humanity" ("nāsūt") and "divinity"

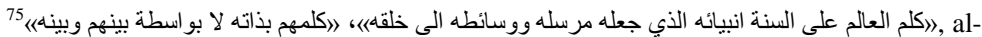
Khazrajī, Maqūmi', 32. 70-71.

"العلى لسان جسدهم الموتحد كان منه، الى معرفته بغير رسول بينه وبينهم), al-Baṣrī, Kitāb al-burhānn,

${ }^{77}$ 《أم النور》, al-Khazrajī, Maqāmi', 32.

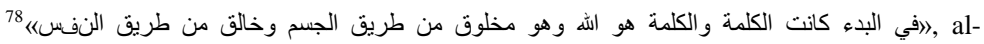
Khazrajī, Maqāmi', 32.

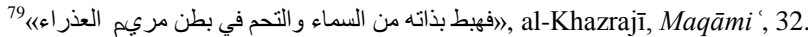

${ }^{80}$ Several scholars suggest the uniqueness of this term to the Arabicized Christians of medieval Iberia; see Sarrió Cucarella, Muslim-Christian Polemics, 92; Potthast, Christen und Muslime im Andalus, 325; Burman, Religious Polemic, 70, 161. For a primary example, see John's prologue in Munich, Bayerische Staats Bibliothek, Cod.Ar. 238, 72r.

${ }^{81}$ In the same manuscript, the preface to the Gospel of John explains that "the Word became flesh, meaning he was embodied” (الكلمة صارت لحمة يعني تجسد))), Munich, Bayerische Staats Bibliothek, Cod.Ar. 238, 71r. 32.

او أمه كانت من قبله بالناسوت وهو كان من قبلها باللاهوت وهو الالاه التامه2), al-Khazrajī, Maqāmi ,
} 
("nāhūt") reflect Latin's "humanitas" and "divinitas" used to describe the two natures of Christ; "he is the perfect divinity" unites both these natures in one subject. For al-Bașrī, Christ is a divine person and human person united through one name, not one person. ${ }^{83}$

Risāla, consequently, appears to draw on a Nestorian tradition in language and argument, but nonetheless alters this language in such a way to make it identifiable with the Latin Christian archive to which the Mozarabs were heir. This is not unusual: themes, arguments, and vocabulary in Christian-Arabic are often shared and recycled across Christological divides, as witnessed in the works of the Melkite Abū Qurra (d. ca. 825), the Jacobite Abū Rā'ița (d. ca. 850), and al-Bașrī. Christian communities held enough in common to warrant such borrowing, and the authors do not appear to consider such synthesis a threat to their identity. Indeed, al-Bașrī downplays difference in Kitāb alburhān: though there is disagreement on how to describe it, "all [Christian sects] agree on the Creator's appearance in their body." 84 Yet, as suggested above, al-Bașrī maintains a notably two-person Christology. Al-Qūṭ̂ does nothing less - he appropriates the argument of another, but within the limits of his tradition. The ultimate example of this may be precisely what has raised so much doubt among scholars regarding Risāla's authenticity. Al-Qūṭ̂̀'s invitation for a Muslim to confess, "The Messiah is the son of God who is God and by the Holy Spirit three hypostases one hypostasis" is illogical. ${ }^{85}$ What competent author, Christian or otherwise, would write such a statement? However, it may be that the Arabic hides a subtext in Latin. Subordinating the phrase "he who is God and by the Holy Spirit three hypostases" allows "one hypostasis" to function as complement in the main clause, rendering, "The Messiah is the son of God [. . .] one hypostasis." This reading corresponds with the work's Theotokos theology, its use of "divinity" and "humanity" to describe Christ, and the context of its origin (Toledo).

Consequently, borrowing from other Christian groups, such as speaking of Christ's humanity as a veil, need not skew religious identity. Indeed, the term veil is not unique to Nestorian environments. As previously discussed, it appears in Sunnī theology with much the same meaning, and al-Ash arī employs it in his polemic against the Jahmìya and Christians generally. With regards to Christian tradition, the idea

\footnotetext{
${ }^{83}$ Al-Bașrī, Kitāb al-burhān, 70.

اجتماعهم على الخالق بظهوره في جسدهم)" al-Bașrī, Kitāb al-burhān, 78-79.

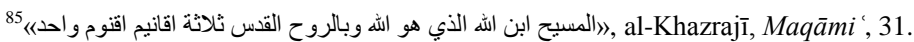


appears quite early. ${ }^{86}$ Origen (d. ca. 254) views the letter of Scripture like the flesh of Christ, veils through which unbelievers cannot perceive the divine truth hidden within, but also the means by which believers gain access to it. ${ }^{87}$ Origen's work was important for the Latin tradition as exegetical method. ${ }^{88}$ Thus, the Carolingian theologian Hrabanus Maurus (d. 856) cites Origen in his Expositionum in Leviticum. He cautions his reader that the letters of Leviticus conceal a deeper meaning: "As in the last days the Word of God came forth into this world from the Virgin Mary clothed in the flesh, and one thing was what was seen, and another was what was hidden. ${ }^{.89}$ Hrabanus explains that revelation has body and soul, letter and meaning, "For as there in [the veil of the] flesh, so here [the spiritual sense] is hidden with the veil of the letter." ${ }^{, 90}$ Moreover, the Vulgate likens Christ's flesh to a "veil." For example, Hebrews 10 says that Christ established a "new and living way" into the Holy of Holies "per velamen id est carnem suam." ${ }^{\text {"I }}$ In Paul's theology, the veil not only

${ }^{86}$ On this development starting with Origen in the Greek, whose importance extends into the Latin Middle Ages, see Beryl Smalley, The Study of the Bible in the Middle Ages (New York, 1952), 1-24; Henri de Lubac, Medieval Exegesis: The Four Senses of Scripture, trans. Mark Sebanc, vol. 1 (Grand Rapids, 1998), 3-7, 15, 142-59, 161-72; and, Frans van Liere, An Introduction to the Medieval Bible (New York, 2013), 119. Abigail Firey discusses Scripture as veil and its relationship to Christ's flesh in the Carolingian context and indicates its debt to Origen in "The Letter of the Law: Carolingian Exegetes and the Old Testament," in With Reverence for the Word: Medieval Scriptural Exegesis in Judaism, Christianity, and Islam, ed. Jane Dammen McAuliffe, et al. (Oxford, 2010), 20424.

${ }^{87}$ For an example of this approach in Origen's work, see In Leviticum homilia I, PG 12 , 405. Also see Firey, "The Letter of the Law," 207 and n. 33, p. 216; and, Smalley, The Study of the Bible, 1-13.

${ }^{88}$ See two notes above, especially Lubac, Medieval Exegesis, 161-72. Origen was likewise important for Iberian exegetes, often through Jerome, as documented in the eighth and ninth centuries; see, again, Lubac, Medieval Exegesis, 163, 167; Joaquin González Echegaray, "Introducción general," in Beato de Liébana, Obras completas y complementarias, ed. González Echegaray et al., vol. 1 (Madrid, 2004), xvi; and Pedro P. Herrera Roldán, Cultura y lengua latinas entre los mozárabes cordobeses del siglo IX (Córdoba, 1995), 53-56. Further, Jerome, fundamental for the Mozarabs (whether writing in Latin or Arabic), owes a well-recognized intellectual debt to Origen's exegetical practices; see, for example, Ronald E. Heine, The Commentaries of Origen and Jerome on St Paul's Epistle to the Ephesians (Oxford, 2002).

89 "Sicut in novissimis diebus Verbum Dei ex Maria virgine carne vestitum processit in hunc mundum, et aliud quidem erat quod videbatur, in eo, aliud quod tegebatur," Expositionum in Leviticum, PL 108, 147. Also see Firey, "The Letter of the Law," 207.

\footnotetext{
90 "Nam sicut ibi carnis, ita hic [spiritalis sensus] litterae velamine tegitur," PL 108,
} 148. 
hides, but also opens access to the divine. In the Iberian context, Beatus exemplifies this tradition. Like Origen before him and Hrabanus after, Beatus speaks of Christ's divinity "clothed in the garment of flesh." ${ }^{92} \mathrm{He}$ then criticizes Elipandus for not recognizing the spiritual meaning of Christ's flesh or the letter of Scripture, "veils" for the divine reality that escapes the bishop. ${ }^{93}$

The concept of Christ's flesh as "veil," then, is common to Christian tradition and crosses dogmatic boundaries. The proposed readings of Mașhaf, Tathlìth, and Risāla suggest as much, since these texts employ "veil" in such a way as to be consonant with Latin tradition. The annotations in MS 10018 are a further case in point. Beatus's work occupies folios 1r-88r of MS 10018. Arabic commentary, in the same hand as that found in Samson's work, fills the margins. The reader focuses on the passages where Beatus discusses Christ's humanity and its relation to the letter of sacred text. The Mozarab's comments mirror the Latin, much like the annotations in Samson's work. For example, when Beatus speaks of Christ's body as the letter of Sacred Scripture, without which one has no access to the divine, the Mozarab writes, "The function of the letters is flesh, what is understood in them is spirit." "The Latin author develops the book analogy further by arguing that Christ reveals what is hidden, just as the Gospel reveals what was veiled in the Law; the Incarnation is both inward and outward reality. The Arabic marginalia reads, "The Messiah is the sacred book [. . .] so understand how it was written inside and out." 95 Curiously, whereas the annotations in Samson's text do employ "veil," these do not. Nonetheless, the Latin text to which they correspond develops the veil analogy at length. The fact that the marginalia are in Arabic places them in the religious dialogue of the Mediterranean, but the annotators engaged in this dialogue by appealing to Latin Christian thought and, in a sense, carrying it forth as its heirs.

\footnotetext{
${ }^{91}$ Hebrews 10:20 in Biblia sacra iuxta vulgatam versionem, ed. Robert Weber, $4^{\text {th }}$ ed. (Stuttgart 1994).

92 "[C]arnis vestimento indutus," Beato de Liébana, Obras completas y complementarias, 714. On Beatus's Christology in general, see John C. Cavadini, The Last Christology of the West: Adoptionism in Spain and Gaul, 785-820 (Philadelphia, 1993).

${ }^{93}$ Beato de Liébana, Obras completas, 796, 808-10.

94 (فعل الاحرف جسما ما افهم فيها نفسنائ, MS 10018, 38v; the Latin text of the manuscript corresponds to Beatus, Obras completas, 782.

95 "المسيح هو المصحف . . . فافهم كيف كان مكتوبا داخلا وخارجای, MS 10018, 55v; the Latin passage to which the Arabic corresponds may be found in Beatus, Obras completas, 800.
} 
CONCLUSION: APPROXIMATION, ASSIMILATION, AND THE FrontiERS OF RELIGIOUS IDENTITY

The present article has argued that the Mozarabic authors of Mașhaf al'ālam al-kā'in, Tathlìth al-wahdānīya, Risālat al-Qūtūi, and the annotations of BNE MS 10018 constructed their religious identity through the appropriation of a linguistic and conceptual archive common to the Islamic Mediterranean. More specifically, it has argued that this appropriation did not result solely or even primarily in the erosion of religious frontiers and the sense of continuity that grounds religious identity. Rather, linguistic and conceptual approximation became the very means by which boundaries could be constructed. Adopting the language of Islamic kalām, for example, allowed for a clearer articulation of what divided Islam from Christianity than would be possible in Latin. And subtle distinctions within Mașhaf and Tathlith suggest an effort to avoid the adoption of Christologies considered heretical in the West, while Risāla and the annotations in MS 10018 more overtly lay claim to the Latin tradition in their Christology. Thus, the Latin Christian identity of the Mozarabs does not end with the Latin works of the ninth century, nor does a sense of "religious community" dissolve with their assimilation into the Arabic culture of al-Andalus. The current reading also has broader significance for what convivencia sometimes meant, neither total rejection nor total accommodation. The religious purity guaranteed through linguistic purity seems an ideal to which few Mozarabic writers aspired, but they were agents in their assimilation into the Mediterranean context, negotiating it in creative and thoughtful ways. Finally, the Mozarabs' assimilation and intellectual engagement with Islam and the Christian traditions of the East did not always result in a more tolerant view of other traditions. All religious identities make a claim, whether explicit or implicit, and such claims are present in the texts studied here. In them, one finds a concerted attempt to articulate tradition and boundaries more clearly within a multi-confessional environment in which religious identity was perceptibly at risk.

\section{Denison University}




\section{Bibliography}

Aillet, Cyrille. Introduction to ¿Existe una identidad mozárabe?: historia, lengua y cultura de los cristianos de al-Andalus (siglos IXXII). Edited by Cyrille Aillet, Mayte Penelas, and Philippe Roisse, ix-xvi. Madrid: Casa de Velázquez, 2008.

- Les mozarabes. Christianisme, islamisation et arabisation en péninsule Ibérique (IX $X^{e}-X I I^{e}$ siècle). Madrid: Casa de Velázquez, 2010 .

—. "Recherches sur le christianisme Arabisé.” In ¿Existe una identidad mozárabe? Historia, lengua y cultura de los cristianos de alAndalus (siglos IX-XII). Edited by Cyrille Aillet, Mayte Penelas, and Philippe Roisse, 109-28. Madrid: Casa de Velázquez, 2008.

al-Ash'arī, Abū al-Hasan. "Fașl ākhar fĩ ibānat madhhabihi fī kalām allāh.” In Abū Bakr b. Fūrak, Mujarrad maqālāt al-shaykh Abī alHasan al-Ash 'arī. Edited by Daniel Gimaret, 59-69. Beirut: Dār alMashriq, 1987.

—. al-Ibāna 'an ușūl al-diyāna. Edited by Bashīr Muhammad 'Uyūn, $3^{\text {rd }}$ edition. Damascus: Dār Ibn Zaydūn, 1999.

-. Kitāb al-luma' fì al-radd'alā ahl al-zigh wa-l-bda'. Edited by Hamūda Ghurāba. Cairo: Maṭba' tMiṣr, 1955.

al-Bașrī, 'Ammār. Kitāb al-burhān. In Apologie et controversies. Edited by Michel Hayek, 19-238. Beirut: Dār al-Mashriq, 1977.

Beatus and Etherius. Heterii et Sancti Beati ad Elipandum epistola. Ninth Century. MS 10018. Fols. 1-88. Biblioteca Nacional de España, Madrid.

Burman, Thomas. Religious Polemic and the Intellectual History of the Mozarabs, ca. 1050-1200. Leiden: Brill, 1994.

Cecilio Díaz y Díaz, Manuel. "Los mozárabes: una minoría combativa." In ¿Existe una identidad mozárabe? Historia, lengua y cultura de los cristianos de al-Andalus (siglos IX-XII). Edited by Cyrille Aillet, Mayte Penelas, and Philippe Roisse, 1-8. Madrid: Casa de Velázquez, 2008.

Coope, Jessica. The Martyrs of Córdoba: Community and Family Conflict in an Age of Mass Conversion. Lincoln: University of Nebraska Press, 1995. 
El-Bizri, Nader. "God: Essence and Attributes." In The Cambridge Companion to Classical Islamic Theology. Edited by Tim Winter, 121-40. Cambridge: Cambridge University Press, 2008. https://doi.org/10.1017/CCOL9780521780582.007

Firey, Abigail. "The Letter of the Law: Carolingian Exegetes and the Old Testament." In With Reverence for the Word: Medieval Scriptural Exegesis in Judaism, Christianity, and Islam. Edited by Jane Dammen McAuliffe, Barry D. Walfish, and Joseph W. Goering, 204-24. Oxford: Oxford University Press, 2010.

González Echegaray, Joaquin. "Introducción general." In Obras completas y complementarias de Beato de Liébana. Vol. 1. Edited by Joaquin González Echegaray, Alberto del Campo, and Leslie G. Freeman. Madrid: Biblioteca de Autores Cristianos, 2004.

Griffith, Sidney H. The Church in the Shadow of the Mosque: Christians and Muslims in the World of Islam. Princeton: Princeton University Press, 2008.

Heine, Ronald E. The Commentaries of Origen and Jerome on St Paul's Epistle to the Ephesians. Oxford: Oxford University Press, 2002. https://doi.org/10.1093/0199245517.001.0001

Herrera Roldán, Pedro P. Cultura y lengua latinas entre los mozárabes cordobeses del siglo IX. Córdoba: Universidad de Córdoba, 1995.

Hitchcock, Richard. Mozarabs in Medieval and Early Modern Spain: Identities and Influences. Hampshire: Ashgate, 2008.

al-Injīl. 1393. MS Cod. Arab. 238. Bayerische Staatsbibliothek, Munich.

al-Jabbār b. Aḥmad al-Asad Abādī, 'Abd. al-Uṣūl al-khamsa. Edited by Fayșal Badīr 'Awn. Kuwait: Kuwait University, 1998.

Kaddouri, Samir. 'Identificación de 'al-Qurțubī', autor de al-I 'ām bimā fì dìn al-nașārā min al-fasād wa-l-awhām." Al-Qantara 21 (2000): 215-19.

Kassis, Hanna. "Arabic-Speaking Christians in al-Andalus in an Age of Turmoil (Fifth/Eleventh Century until A.H. 478/A.D. 1085)." AlQantara 15, no. 2 (1994): 401-22.

al-Khazrajī̄, Aḥmad b. 'Abd al-Șamad. Maqāmi' al-ṣulbān. Edited by 'Abd al-Majīd al-Sharfī. Tunis: al-Sharika al-Tūnisīyya li-Funūn alRasm, 1975.

Koningsveld, P. Sj. Van. "Christian Arabic Literature from Medieval Spain: An Attempt at Periodization." In Christian Arabic 
Apologetics During the Abbasid Period (750-1258). Edited by Samir Khalil Samir and J. S. Nielsen, 203-24. Leiden: Brill, 1994.

Lubac, Henri de. Medieval Exegesis: The Four Senses of Scripture. Vol.

1. Translated by Mark Sebanc. Grand Rapids: Eerdmans, 1998.

Menocal, Maria Rosa. Ornament of the World: How Muslims, Jews and Christians Created a Culture of Tolerance in Medieval Spain. Boston: Bay Back Books, 2002.

Monferrer Sala, Juan Pedro. “Circularon textos cristianos orientales en al-Andalus?: Nuevos datos a partir de una muestra vétero testamentaria andalusí." In ¿Existe una identidad mozárabe? Historia, lengua y cultura de los cristianos de al-Andalus (siglos $I X-X I I)$. Edited by Cyrille Aillet, Mayte Penelas, and Philippe Roisse, 167-210. Madrid: Casa de Velázquez, 2008.

Nagel, Tilman. The History of Islamic Theology: From Muhammad to the Present. Translated by Thomas Thornton. Princeton: Markus Wiener Publishers, 2000.

Nirenberg, David. Neighboring Faiths: Christianity, Islam, and Judaism in the Middle Ages and Today. Chicago: University of Chicago Press, 2014.

https://doi.org/10.7208/chicago/9780226169095.001.0001

Origen. In Leviticum Homilia I, Patrologia Graeca 12:405-11.

Pavlin, James. "Sunni kalām and theological controversies." In History of Islamic Philosophy. Edited by Sayyed Hossein Nasr and Oliver Leaman, 105-18. London: Routledge, 1996.

Penelas, Mayte. "El Kitāb Hurūšiyūš y el 'Texto mozárabe de la historia universal' de Qayrawān: Contenidos y filiación de dos crónicas árabes cristianas.” In ¿Existe una identidad mozárabe? Historia, lengua y cultura de los cristianos de al-Andalus (siglos IX-XII). Edited by Cyrille Aillet, Mayte Penelas, and Philippe Roisse, 13457. Madrid: Casa de Velázquez, 2008.

-. 'Linguistic Islamization of the 'Mozarabs' as attested in a late ninthcentury chronicle." In Language of Religion-Language of the People: Medieval Judaism, Christianity and Islam. Edited by Ernst Bremer, Jörge Jamut, Michael Richter, and David J. Wasserstein, 103-14. Munich: Wilhelm Fink Verlag, 2006.

Pérez Marinas, Iván. Sansón de Córdoba: vida y pensamiento. Madrid: Ediciones de la Ergastula, 2012. 
Potthast, Daniel. Christen und Muslime im Andalus: Andalusische Christen und ihre Literatur nach religionspolemischen Texten des zehnten bis zwölften Jahrhunderts. Wiesbaden: Harrassowitz Verlag, 2013.

al-Qurțubī, al-Imām. al-I 'ā̄m bi-mā fì dīn al-nasārāmin al-fasād waawhām wa-iẓhārmahāāin dīn al-islām wa-ithbātnubūwatnabīnā Muḥammad 'alayhi al-ṣalāt wa-al-salām. Edited by Aḥmad Hijāzī al-Saqqā. Cairo: Dār al-Turāth al-'Arabī, 1980.

Renard, John, ed. Islamic Theological Themes: A Primary Source Reader. Oakland: University of California Press, 2014.

Safran, Janina M. Defining Boundaries in al-Andalus: Muslims, Christians, and Jews in Islamic Iberia. Ithaca: Cornell University Press, 2013.

https://doi.org/10.7591/cornell/9780801451836.001.0001

Samson of Córdoba. Apologeticus contra perfidos. In Corpus scriptorium muzarabicorum, vol. 2. Edited by Juan Gil, 506-658. Madrid: Instituto Antonio de Nebrija, 1973.

-. Liber apologeticus. Ninth Century. MS. 10018. Fols. 89-180. Biblioteca Nacional de España, Madrid.

Sarrió Cucarella, Diego R. Muslim-Christian Polemics Across the Mediterranean: The Splendid Replies of Shihāb al-Dīn al-Qarāfì (d. 864/1285). Leiden: Brill, 2015.

https://doi.org/10.1163/9789004285606

Scarborough, Connie. "Introduction." In Revisiting Convivencia in Medieval and Early Modern Iberia. Edited by Connie Scarborough, 9-30. Newark, Delaware: Juan de la Cuesta-Hispanic Monographs, 2014.

al-Shahrastān̄̄, Muḥammad b. 'Abd. al-Milal wa-l-nahal. Edited by Aḥmad Fahmī Muḥammad, $2^{\text {nd }}$ ed. Beirut: Dār al-Kitāb al-'Ilmīyya, 1992.

-. "Divergent Schools of Thought: Shahrastān̄̄'s Doxography of Muslim Schools." Translated by Michael A. Sells. In Islamic Theological Themes: A Primary Source Reader. Edited by John Renard, 137-45. Oakland: University of California Press, 2014.

Smalley, Beryl. The Study of the Bible in the Middle Ages. New York: The Philosophical Library, 1952. 
Szpiech, Ryan. "Introduction." In Medieval Exegesis and Religious Difference: Commentary, Conflict, and Community in the Premodern Mediterranean. Edited by Ryan Szpiech, 1-26. New York: Fordham University Press, 2015. https://doi.org/10.5422/fordham/9780823264629.001.0001

Tieszen, Charles. Christian Identity amid Islam in Medieval Spain. Leiden: Brill, 2013.

Urvoy, Marie-Thérèse "Influence islamique sur le vocabulaire d'un psautier arabe d'al-Andalus." Al-Qantara 15, no. 2 (1994): 509-17.

Van Liere, Frans. An Introduction to the Medieval Bible. New York: Cambridge University Press, 2013.

Weber, Robert, and Robert Gryson, eds. Biblia sacra iuxta Vulgatam versionem. $4^{\text {th }}$ ed. Stuttgart: Deutsche Bibelgesellschaft, 1994.

Wolf, Kenneth Baxter. "Convivencia in Medieval Spain: A Brief History of an Idea." Religion Compass 3, no. 1 (2009): 72-85. https://doi.org/10.1111/j.1749-8171.2008.00119.x 